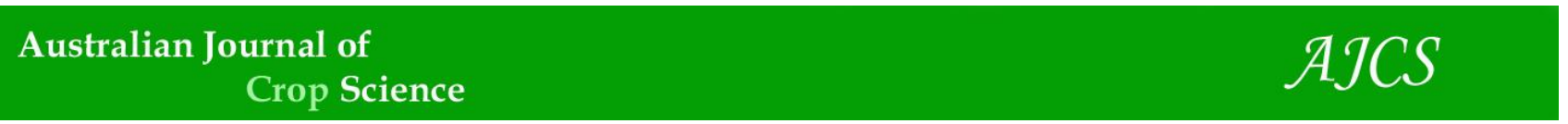

AJCS 14(11):1756-1763 (2020)

ISSN:1835-2707

doi: 10.21475/ajcs.20.14.11.p2509

\title{
Effects of liming on the growth and nutrient concentrations of pitaya species in acidic soils
}

\author{
Letícia Alves Carvalho Reis ${ }^{1}$, Maria do Céu Monteiro Cruz ${ }^{2 *}$, Enilson de Barros Silva ${ }^{2}$, Josimara Mendes \\ Rabelo ${ }^{2}$, Cintia Maria Teixeira Fialho ${ }^{3}$
}

\author{
${ }^{1}$ Department of Plant Agriculture at the University of Guelph, Guelph, Ontario, Canada \\ ${ }^{2}$ Department of Agronomy at the Federal University of Jequitinhonha and Mucuri Valleys, Diamantina, Minas \\ Gerais, Brazil \\ ${ }^{3}$ Department of Agronomy at the Federal Technological University of Paraná, Santa Helena, Paraná, Brazil
}

\section{*Corresponding author: mariceu@ufvjm.edu.br}

\begin{abstract}
With the increasing demand for pitaya orchard management information to achieve high productivity and commercial quality fruits, liming practice is fundamental since most Brazilian soils are acidic. This study aims to assess lime requirements of Typic Quartzipisamment and Haplorthox soils to calculate tolerated aluminum saturation, desired base saturation, calcium and magnesium requirements to cultivate two pitaya species; Hylocereus undatus and Hylocereus polyrhizus. Two independent experiments were conducted in a greenhouse, organized in a $2 \times 4$ factorial scheme. Treatments were distributed in randomized blocks with five replications. Treatments of the first experiment corresponded to $H$. undatus and $H$. polyrhizus and four lime requirements, $0 ; 0.8 ; 1.2$ and $1.7 \mathrm{t} \mathrm{ha}^{-1}$ cultivated in Typic Quartzipisamment. Treatments of the second experiment corresponded to $H$. undatus and $H$. polyrhizus and four lime requirements, $0 ; 1.3 ; 2.0$ and $2.8 \mathrm{t}^{-1}$ cultivated in Haplorthox. Shoot and root dry matter, chemical soil attributes and shoot nutrient concentrations were measured. Regression equations were adjusted for each variable, according to the lime requirements of both soils providing the highest dry matter yield in both pitaya species. $H$. undatus and $H$. polyrhizus cultivated in Typic Quartzipisamment produced more dry matter when the aluminum saturation was between $13 \%$ and $16 \%$, base saturation $70 \%$ and the calcium and magnesium requirement $2.5 \mathrm{cmol}_{c} \mathrm{dm}^{-3}$. H. undatus and $H$. polyrhizus cultivated in Haplorthox produced more dry matter when the aluminum saturation was between $1 \%$ and $4 \%$, base saturation between $55 \%$ and $70 \%$, and calcium and magnesium requirement $3.0 \mathrm{cmol}_{\mathrm{c}} \mathrm{dm}^{-3}$.
\end{abstract}

Keywords: soil pH; base saturation; Hylocereus polyrhizus; Hylocereus undatus; management.

Abbreviation: H. undatu_Hylocereus undatus, H. polyrhizus_Hylocereus polyrhizus, t_tonnes, ha $^{-1}$ _hectares.

\section{Introduction}

Information on the appropriate soil attributes for pitaya cultivation in producing regions is incipient. Soils with a $\mathrm{pH}$ between 5.5 and 6.5 are considered ideal for pitaya cultivation (Mizrahi and Nerd, 1999; Gunasena et al., 2006). In the producing regions of China, most pitaya orchards are grown in an acidic $\mathrm{pH}$ range. However, it was reported that there was a reduced amount of $\mathrm{N}$ available to the plants after planting (Huang et al., 2017), demonstrating the importance of performing adequate soil correction to promote the growth of pitaya plants. Thus, information about the tolerance of exchangeable aluminum, base saturation and the calcium and magnesium requirement is necessary. Pitaya orchard management has been conducted differently in each cultivation region, resulting in variable yields, which may be related to several factors, including plant age, planting density, climatic conditions of the region and chemical attributes of the orchard soil. Meeting the nutritional requirements of fruit plants is one of the determining factors for these plants to reach their productive potential. For the cultivation of fruit species, specifically perennial plants, the ideal conditions for growth include deep and permeable soils for the plants to develop their root systems. Roots are not able to develop satisfactorily under acidic and nutrient-poor soil conditions due to aluminum toxicity and calcium deficiency (Natale et al., 2012). Thus, liming and fertilization is essential for adequate root development. Almost one third of the planet's fertile land is covered by acidic soils (Sikiric et al., 2011). Most Brazilian soils are acidic and the lack of some chemical elements are due to the lack of basicity of the rocks, climatic conditions related to high temperature and precipitation (Natale et al., 2008). Cation leaching processes, mainly $\mathrm{Ca}^{2+}$ and $\mathrm{Mg}^{2+}$, allow the soil cation exchange complex to be dominated by $\mathrm{H}^{+}$and $\mathrm{Al}^{3+}$ ions, resulting in soil toxicity to plants (Mijangos et al., 2010). For agricultural regions where soils are acidic, liming is an essential process to precipitate toxic aluminum, raise the $\mathrm{pH}$ and provide calcium and magnesium to plants (Raij, 2011). Base saturation, $\mathrm{pH}$ and aluminum saturation indices are parameters used to correct soil acidity. Base saturation is an important chemical attribute for plant cultivation because it is related to the supply of bases such as $\mathrm{Ca}, \mathrm{Mg}$ and $\mathrm{K}$ at 
levels suitable for plant development. For species that are less demanding of fertilization, it is recommended to increase soil base saturation to between $30 \%$ and $35 \%$; for demanding species between $40 \%$ and $45 \%$ and for very demanding species it is recommended to increase base saturation by $50 \%$ to $60 \%$ (Vilela et al., 2004). Raising and maintaining soil pH between 6.0 and 6.5 is recommended to stabilize soil chemical characteristics and make essential plant nutrients available (Sousa et al., 2007; Rothwell et al., 2015). In acidic soils with a pH lower than 5.5, the dissolution of Al forms tend to increase (Vitti et al., 2006), with a decline in production (Manna et al., 2007). Aluminum saturation ( $\mathrm{m} \%$ ) expresses soil toxicity, and also refers to the percentage of effective capacity of exchanging cations occupied by aluminum. High aluminum saturation values indicate that the soil is acidic and may contain $\mathrm{Al}^{3+}$ at a toxic level to plants (Gorski et al., 2019). Most crop yields can be improved by practicing liming on acidic soils, and the soil type influences the relationship between yield and soil $\mathrm{pH}$ for crops (Farhoodi and Coventry, 2008; Goulding, 2016; Liu et al., 2004). The lime requirement is not only related to $\mathrm{pH}$, aluminum saturation and base saturation, but also to the buffering capacity and cation exchange capacity of soils. Clay soils require more limestone to raise the $\mathrm{pH}$ in comparison to sandy soils, since the buffering capacity is directly related to the clay and organic matter content of the soil, as well as the type of clay (Sousa et al., 2007). With regard to liming for pitaya cultivation, studies are still in demand. Research related to lime requirement in pitaya orchards is essential for the expansion of new cultivation areas in Brazil. This research would enable the recommendation of liming necessary for the establishment and maintenance of orchards, since pitaya species are perennial. This research was conducted to evaluate the lime requirement to be able to calculate the tolerated aluminum saturation, the desired base saturation and the calcium and magnesium requirements for pitaya cultivation in Typic Quartzipisamment and Haplorthox soils.

\section{Results and Discussion}

\section{Shoot and root dry matter production}

The analysis of variance results for the dry matter of shoots and roots demonstrated a interaction between lime requirements and pitaya species $(p<0.01)$ in Typic Quartzipisamment and Haplorthox soils. The regression models were adjusted according to the lime requirements in Typic Quartzipisamment and Haplorthox soils for pitaya species Hylocereus polyrhizus and Hylocereus undatus (Fig 1 and Fig 2). The lime requirement that resulted in the most growth of pitaya species cultivated in Typic Quartzipisamment soil was $1.7 \mathrm{t} \mathrm{ha}^{-1}$ (Fig 1). With liming in Typic Quartzipisamment soil, the dry matter production in $\mathrm{H}$. polyrhizus increased by $53.9 \%$, in relation to the dry matter of the plants that grew in soil without liming conducted. A similar result was observed in the species $H$. undatus, which showed an increase of $156.6 \%$ in relation to the cultivated plants without liming. The lime requirement that provided the most growth of $H$. polyrhizus plants in Haplorthox soil was $1.9 \mathrm{t} \mathrm{ha}^{-1}$. The dry matter of shoots and roots increased by $185.9 \%$ in relation to the plants grown without liming conducted. For $H$. undatus species, the lime requirement in Haplorthox soil providing the most plant growth was $2.8 \mathrm{t}$ $\mathrm{ha}^{-1}$. Dry matter in this treatment increased by $136.6 \%$ compared to the plants grown without liming practice (Fig 2). The results observed in relation to dry matter production demonstrate that the pitaya species respond differently to liming in different types of soil. In Typic Quartzipisamment soil, the species $H$. undatus presented a superior response compared to $H$. polyrhizus with liming conducted, which can be attributed to the vigor of this species since it emits more shoots under favorable conditions, such as the availability of nutrients like $\mathrm{K}, \mathrm{Ca}$ and $\mathrm{Mg}$. In Haplorthox soil, the highest lime requirement observed for the highest dry matter production, specifically for pitaya, is related to the buffer capacity of the studied soils, which was influenced by the cation exchange capacity and the higher clay concentration in this type of soil (Table 1). The most growth of the plants was observed after the application of limestone in both soils. This was due to the fact that in addition to increasing the availability of important nutrients for root development, such as $\mathrm{Ca}$, there was a rise in $\mathrm{pH}$, a reduction of toxic aluminum and an increase in base saturation to the plants (Table 2). The soil of the root environment became satisfactory with liming, which can be positively correlated with dry matter production. The adequate formation and development of the root system is critical for pitaya and other perennial fruit species that use the same volume of soil for long periods of time (Natale et al., 2012). It is also important to form sufficient roots for the absorption of water and nutrients with the exploitation of a greater volume of soil. This allows orchards to form and expand rapidly, enabling the plants to produce fruit in a shorter amount of time following initial planting. Liming is a fundamental practice to improve the root environment when planting pitaya, and it is considered a primary condition for productivity gains and maintenance of orchards during production (Raij et al., 1997).

The results demonstrate that soil acidity interferes with the growth of pitaya and therefore must be corrected to allow the satisfactory growth of the plants and enable high orchard yields.

\section{Effect of Liming on chemical soil attributes}

Pitaya species ( $H$. undatus and $H$. polyrhizus) $(p<0.01)$ reacted to liming performed for almost all chemical attributes of the Haplorthox and Typic Quartzipisamment soils, except for $\mathrm{K}$ saturation (Table 2).As for chemical soil attributes, it was observed that liming increased the soil $\mathrm{pH}$, $\mathrm{K}, \mathrm{Ca}$ and $\mathrm{Mg}, \mathrm{Ca}$ saturation, $\mathrm{Mg}$ saturation and base saturation (Table 2). The observed results for $\mathrm{K}$ saturation showed that increases in lime requirements may be related to the low values observed in soils prior to liming (Table 1). By comparing the $\mathrm{pH}$ reached in soils after liming was conducted, it is possible to observe that the application of limestone had less of an effect on Haplorthox soil. In Haplorthox soil, there was an increase in the $\mathrm{pH}$ from 5.9 to 6.6 , with the lime requirement at $1.9 \mathrm{t} \mathrm{ha}^{-1}$ for $\mathrm{H}$. polyrhizus, and an increase from 5.9 to 6.7 with the lime requirement at $2.8 \mathrm{t} \mathrm{ha}^{-1}$ for $H$. undatus. In comparison, Typic Quartzipisamment soil increased the $\mathrm{pH}$ from 5.1 to 7.0 for $H$. undatus and 5.3 to 7.0 for $H$. polythizus, with the lime requirement at $1.7 \mathrm{t} \mathrm{ha}^{-1}$ (Table 2 ). The observed results demonstrate that the growth of the two pitaya species is impacted by acidic soil conditions. In the studied soils, the highest growth of the pitaya species occurred when the $\mathrm{pH}$ was between 6.6 and 7.0, a range that is above the ideal 
amount for most fruit species, which usually develops in soils with a pH between 6,0 and 6.5 (Sousa et al., 2007).

Knowledge of the appropriate soil chemical attributes for the growth of pitaya species is important to establish appropriate soil cultivation management. Knowledge is one of the factors that has caused variation in global orchard productivity, since soils with a pH between 5.5 and 6.5 in many countries are considered ideal for the cultivation of pitaya species (Gunasena et al., 2006). A lack of information for Brazilian soils is still prevalent today.

The observed elevation of soil nutrient concentration occurs because liming favors the maintenance of an exchangeable $\mathrm{K}$ concentration in the soil. This is due to the increase of an effective cation exchange capacity and also due to the fact that limestone is a source of $\mathrm{Ca}$ and $\mathrm{Mg}$. These results are important for the growth of pitaya species, considering that the perenniality of these plants will benefit from this fundamental management practice. In some cases, the availability of $\mathrm{K}$ to plants may increase more than $\mathrm{Ca}$ and $\mathrm{Mg}$, due to the lower degree of attraction of $\mathrm{K}$ by the negative soil loads. The availability of nutrients to pitaya species, such as $\mathrm{Ca}$ and $\mathrm{K}$, is important for plant growth because both nutrients are among the most demanding for dry matter production (Moreira et al., 2016, Rabelo et al., 2020). In addition, the cultivation of pitaya species with the availability of $\mathrm{Ca}$ reduces plant susceptibility to diseases (Valencia Botín et al., 2003). In relation to base saturation, the best results were observed between $68.6 \%$ and $69.5 \%$ in Typic Quartzipisamment soil and between $55.5 \%$ and $70.4 \%$ in Haplorthox soil after liming (Table 2). The results indicate that both pitaya species are fertility-demanding, with a higher dry matter yield when the base saturation was above $50 \%$ in both soils, since it is recommended to increase the saturation by bases between $50 \%$ and $60 \%$ for nutrient demanding species (Vilela et al., 2004). To cultivate pitaya species, the maintenance of base saturation is important since there are small amounts of cations, such as $\mathrm{Ca}^{2+}, \mathrm{Mg}^{2+}$ and $\mathrm{K}^{+}$under acid soil conditions, which saturate the negative charges of the colloids while most of them are neutralized by $\mathrm{H}^{+}$and $\mathrm{Al}^{3+}$. This maintenance may be established prior to orchard implantation, which will limit the growth of plants after field planting or the acidification process may be accentuated and consequently lead to a loss of soil fertility. Soil fertility will be reduced due to the removal of exchangeable cations from the surface of the colloids which may occur through rainwater, orchard irrigation, decomposition of clay minerals, ion exchange of roots, decomposition of organic matter and/or the addition of nitrogen fertilizers (Natale et al., 2012), which is common in commercial orchards and should therefore be monitored and corrected. The requirements for $\mathrm{Ca}+\mathrm{Mg}$ was $25 \mathrm{mmolc}$ $\mathrm{dm}^{-3}$, aluminum saturation tolerated between $13.1 \%$ and $15.9 \%$, Ca saturation between $32.1 \%$ and $33.7 \%, \mathrm{Mg}$ saturation between $22.8 \%$ and $26.3 \%$ and $\mathrm{K}$ saturation between $11.2 \%$ and $12 \%$, all of which were elements considered adequate for the growth of pitaya species inTypic Quartzipisamment soil. In Haplorthox soil, the requirement for $\mathrm{Ca}+\mathrm{Mg}$ was $30 \mathrm{mmolc} \mathrm{dm}^{-3}$, aluminum saturation tolerated between $0.99 \%$ and $4.4 \%$, Ca saturation between $27.5 \%$ and $34.7 \%$, Mg saturation between $19.6 \%$ and $25.3 \%, \mathrm{~K}$ saturation between $8 \%$ and $10.2 \%$ (Table 2 ). This information is important for the correction of soils, since it is used in the neutralization method of $\mathrm{Al}^{3+}$ and the elevation of exchangeable $\mathrm{Ca}$ and $\mathrm{Mg}$ concentration, which has not yet been reported for pitaya species. Compared to the initial chemical analysis (Table 1), the use of limestone improved soil chemical attributes. It is important to note that in addition to the $\mathrm{pH}$, base saturation and nutrient availability, liming reduces the toxic concentrations of $\mathrm{Al}$ (Table 2). This is because limestone applied to soil forms $\mathrm{Ca}^{2+}, \mathrm{Mg}^{2+}$ and $\mathrm{HCO}^{3-}$ ions, which react with water to form hydroxyl $\mathrm{OH}^{-}$, water and carbon dioxide $\mathrm{CO}_{2}$. The hydroxylates react with the adsorbed $\mathrm{Al}^{3+}$ and $\mathrm{H}^{+}$ions, forming insoluble aluminum hydroxide and water, releasing the charges that will be occupied by the $\mathrm{Ca}^{2+}$ and $\mathrm{Mg}^{2+}$ ions (Malavolta, 2006). The results demonstrated that the lime requirement in each soil will depend on the attributes presented by the soil and that the growth of pitaya species will be proportional to soil management. The pitaya species will grow more when the soil correction achieves satisfactory results in relation to $\mathrm{pH}$ correction, base saturation, saturation by aluminum and the availability of nutrients to the plants.

\section{Effect of liming on plant nutrient concentration}

The concentrations of $\mathrm{P}, \mathrm{Ca}$ and $\mathrm{Mg}$ increased and the concentrations of $\mathrm{N}, \mathrm{K}, \mathrm{Zn}, \mathrm{Mn}$ and Fe decreased in the shoots of both pitaya species with an increasing lime requirement (Table 3 ). The $\mathrm{Ca}$ concentration varied in the two pitaya species between $69 \mathrm{~g} \mathrm{~kg}^{-1}$ and $83.9 \mathrm{~g} \mathrm{~kg}^{-1}$ in Typic Quartzipisamment soil. For pitaya species cultivated in Haplorthox soil, the Ca concentration varied between $67.5 \mathrm{~g}$ $\mathrm{kg}^{-1}$ and $85.9 \mathrm{~g} \mathrm{~kg}^{-1}$. The concentration of $\mathrm{Mg}$ in the two pitaya species ranged from $11.3 \mathrm{~g} \mathrm{~kg}^{-1}$ to $11.6 \mathrm{~g} \mathrm{~kg}^{-1}$ in Typic Quartzipisamment and soil, and it ranged from $11.3 \mathrm{~g} \mathrm{~kg}^{-1}$ and $12.2 \mathrm{~g} \mathrm{~kg}^{-1}$ in Haplorthox soil (Table 3). The availability of nutrients to plants, such as $\mathrm{Ca}$, is important for fruit species to maintain fruit quality and leaf cell structure. There are few studies, which indicate the effects of liming and nutrient concentrations in pitaya dry matter. However, a study carried out in Brazil demonstrated that the use of bioclastic granules, which are limestone algae of the genus Lithothamnium, promoted the growth of $H$. undatus due to soil $\mathrm{pH}$ correction and the availability of $\mathrm{Ca}$ (Moreira et al., 2011). The importance of $\mathrm{Ca}$ to plants is related to their participation in the formation of cell walls, and in the form of calcium pectate, which is the main constituent of the middle lamella and acts to increase the stiffness of the cell wall (Vitti et al., 2006). In addition, $\mathrm{Ca}$ and $\mathrm{Mg}$ deficiencies are due to liming limitations, associated with the susceptibility of pitaya species to diseases with the development of severe symptoms caused by phytopathogens (Valencia Botín et al., 2003). The lowest levels of nutrients in the shoots of the two pitaya species with liming (Table 3) can be attributed to the higher production of dry matter by the plants (Figures 1 and 2). Nutrients in the plants were diluted and presented the most growth, because all the plants received the same amounts of the sources that made these nutrients available. Thus, for pitaya species to reach high yields through satisfactory cladode growth and without a significant reduction of nutrient concentration in dry matter, it is necessary to manage fertilization to meet the demand of the plants. With the soil correction, they present greater growth.

In the plants that presented the most growth, the concentration varied between $9.2 \mathrm{~g} \mathrm{~kg}^{-1}$ and $13.9 \mathrm{~g} \mathrm{~kg}^{-1}$ of $\mathrm{N}$; $5.6 \mathrm{~g} \mathrm{~kg}^{-1}$ and $7.9 \mathrm{~g} \mathrm{~kg}^{-1}$ of $\mathrm{P} ; 14.2 \mathrm{~g} \mathrm{~kg}^{-1}$ and $21.6 \mathrm{~g} \mathrm{~kg}^{-1}$ of $\mathrm{K}$; $70.9 \mathrm{mg} \mathrm{kg}^{-1}$ and $118 \mathrm{mg} \mathrm{kg}^{-1}$ of Fe; $153.6 \mathrm{mg} \mathrm{kg}^{-1}$ and 220.2 $\mathrm{mg} \mathrm{kg}{ }^{-1}$ of $\mathrm{Mn}, 233.6 \mathrm{mg} \mathrm{kg}^{-1}$ and $534.8 \mathrm{mg} \mathrm{kg}^{-1}$ of $\mathrm{Zn}$. In this 
Table 1. Chemical and textural attributes before acidity correction and basic fertilization in theTypic Quartzipisamment and Haplorthox soils.

\begin{tabular}{|c|c|c|c|}
\hline Attribute & unit of measurement & Typic Quartzipisamment & Haplorthox \\
\hline $\mathrm{pH}_{\text {water }}^{\mathrm{a}}$ & - & 5.3 & 5.4 \\
\hline $\mathrm{P}^{\mathrm{b}}$ & $\mathrm{mg} \mathrm{kg}^{-1}$ & 1.9 & 1.2 \\
\hline $\mathrm{K}^{\mathrm{b}}$ & $\mathrm{mmol}_{\mathrm{c}} \mathrm{kg}^{-1}$ & 0.7 & 0.9 \\
\hline $\mathrm{Ca}^{\mathrm{c}}$ & $\mathrm{mmol}_{\mathrm{c}} \mathrm{kg}^{-1}$ & 6.0 & 8.0 \\
\hline $\mathrm{Mg}^{\mathrm{c}}$ & $\mathrm{mmol}_{\mathrm{c}} \mathrm{kg}^{-1}$ & 4.0 & 6.0 \\
\hline $\mathrm{Al}^{\mathrm{c}}$ & $\mathrm{mmol}_{\mathrm{c}} \mathrm{kg}^{-1}$ & 2.1 & 1.1 \\
\hline $\mathrm{CEC}^{d}$ & $\mathrm{mmol}_{\mathrm{c}} \mathrm{kg}^{-1}$ & 23.3 & 37.5 \\
\hline$m^{e}$ & $\%$ & 54.0 & 31.0 \\
\hline$V^{f}$ & $\%$ & 7.0 & 6.0 \\
\hline Sand $^{\mathrm{g}}$ & $\mathrm{g} \mathrm{kg}^{-1}$ & 760 & 365 \\
\hline Loam $^{\mathrm{g}}$ & $\mathrm{g} \mathrm{kg}^{-1}$ & 80 & 175 \\
\hline Clay $^{\mathrm{g}}$ & $\mathrm{g} \mathrm{kg}^{-1}$ & 160 & 460 \\
\hline
\end{tabular}

${ }^{a}$ soil:water 1:2.5; ${ }^{b}$ Mehlich-1 extractor; ${ }^{\mathrm{C} C C l} 1$ mol L ${ }^{-1}$ extractor; ${ }^{d}$ Cation Exchange capacity at pH 7.0; ${ }^{\mathrm{e}}$ Aluminum saturation; ${ }^{\mathrm{f}}$ Base Saturation; ${ }^{\mathrm{B}}$ Sand, silt and clay: Pipette method

Table 2. Regression equation and determination coefficients $\left(R^{2}\right)$ for soil chemical attributes $(\hat{y})$ at varying lime requirements $(x, t$ $\mathrm{ha}^{-1}$ ) for Typic Quartzipisamment and Haplorthox, resulting optimal values for maximum production of Hylocereus undatus and Hylocereus polyrhizusdry matter.

\begin{tabular}{|c|c|c|c|c|c|}
\hline Chemical Attribute & Unit & Regression Equation & $\mathrm{R}^{2}$ & F Test & Optimal value \\
\hline \multicolumn{6}{|c|}{ TypicQuartzipisamment } \\
\hline \multicolumn{6}{|c|}{ Hylocereus polyrhizus } \\
\hline $\mathrm{pH}_{\text {water }}$ & - & $\hat{y}=5.3+1.0204 x$ & 0.97 & $30.8^{* *}$ & 7.0 \\
\hline $\mathrm{K}$ & $\mathrm{mmol}_{\mathrm{c}} \mathrm{kg}$ & $\hat{y}=3.1+1.2008 x$ & 0.99 & $126.1^{* *}$ & 5.1 \\
\hline $\mathrm{Ca}$ & $\mathrm{mmol}_{\mathrm{c}} \mathrm{kg}$ & $\hat{y}=1.9+7.2649 x$ & 0.95 & $20.4^{* *}$ & 14.3 \\
\hline $\mathrm{Mg}$ & $\mathrm{mmol}_{\mathrm{c}} \mathrm{kg}$ & $\hat{y}=1.5+5.9628 x$ & 0.94 & $16.4^{* *}$ & 11.6 \\
\hline $\mathrm{Al}$ & $\mathrm{mmol}_{\mathrm{c}} \mathrm{kg}$ & $\bar{y}=2.155-0.926 x$ & 0.96 & $28.6^{* *}$ & 0.58 \\
\hline Al Saturation & $\%$ & $\bar{y}=36.11-13.53 x$ & 0.95 & $23.6^{* *}$ & 13.1 \\
\hline Base Saturation & $\%$ & $\hat{y}=17.8+30.4686 x$ & 0.96 & $24.4^{* *}$ & 69.6 \\
\hline Ca Saturation & $\%$ & $\hat{y}=4.6+16.1736 x$ & 0.95 & $19.9 * *$ & 32.1 \\
\hline Mg Saturation & $\%$ & $\hat{y}=3.7+13.3063 x$ & 0.95 & $18.5^{* *}$ & 26.3 \\
\hline K Saturation & $\%$ & $\bar{y}=11.2$ & - & $0.3^{\mathrm{ns}}$ & 11.2 \\
\hline \multicolumn{6}{|l|}{ Hylocereus undatus } \\
\hline $\mathrm{pH}_{\text {water }}$ & $\mathrm{mmol}_{\mathrm{c}} \mathrm{kg}^{-1}$ & $\hat{y}=5.1+1.1111 x$ & 0.99 & $106.4^{* *}$ & 7.0 \\
\hline $\mathrm{K}$ & $\mathrm{mmol}_{\mathrm{c}} \mathrm{kg}^{-1}$ & $\hat{y}=4.7+0.3261 x$ & 0.95 & $18.1 * *$ & 5.3 \\
\hline $\mathrm{Ca}$ & $\mathrm{mmol}_{\mathrm{c}} \mathrm{kg}^{-1}$ & $\hat{y}=1.0+8.0743 x$ & 0.99 & $145.7^{* *}$ & 14.7 \\
\hline $\mathrm{Mg}$ & $\mathrm{mmol}_{\mathrm{c}} \mathrm{kg}^{-1}$ & $\hat{y}=0.6+5.5687 x$ & 0.98 & $39.4 * *$ & 10.1 \\
\hline $\mathrm{Al}$ & $\mathrm{mmol}_{\mathrm{c}} \mathrm{kg}^{-1}$ & $\bar{y}=1.971-0.706 x$ & 0.92 & $25.4^{* *}$ & 0.76 \\
\hline Al Saturation & $\%$ & $\bar{y}=51.11-20.12 x$ & 0.97 & $28.4 * *$ & 15.9 \\
\hline Base Saturation & $\%$ & $\hat{y}=16.6+30.5241 x$ & 0.99 & $147.9 * *$ & 68.5 \\
\hline Ca Saturation & $\%$ & $\hat{y}=2.8+18.1673 x$ & 0.99 & $115.6^{* *}$ & 33.7 \\
\hline Mg Saturation & $\%$ & $\hat{y}=1.7+12.4816 x$ & 0.98 & $58.1^{* *}$ & 22.8 \\
\hline K Saturation & $\%$ & $\bar{y}=12.0$ & - & $0.7^{\mathrm{ns}}$ & 12.0 \\
\hline \multicolumn{6}{|l|}{ Haplorthox } \\
\hline \multicolumn{6}{|l|}{ Hylocereus polyrhizus } \\
\hline $\mathrm{pH}_{\text {water }}$ & - & $\hat{y}=5.9+0.3841 x$ & 0.99 & $79.3^{* *}$ & 6.6 \\
\hline $\mathrm{K}$ & $\left(\mathrm{mmol}_{\mathrm{c}} \mathrm{kg}^{-1}\right)$ & $\hat{y}=3.2+0.5488 x$ & 0.95 & $27.3^{* *}$ & 4.3 \\
\hline $\mathrm{Ca}$ & $\left(\mathrm{mmol}_{\mathrm{c}} \mathrm{kg}^{-1}\right)$ & $\hat{y}=1.5+7.4966 x$ & 0.99 & $140.2^{* *}$ & 15.1 \\
\hline $\mathrm{Mg}$ & $\left(\mathrm{mmol}_{\mathrm{c}} \mathrm{kg}^{-1}\right)$ & $\hat{y}=2.3+4.4934 x$ & 0.91 & $19.8^{* *}$ & 10.7 \\
\hline $\mathrm{Al}$ & $\left(\mathrm{mmol}_{\mathrm{c}} \mathrm{kg}^{-1}\right)$ & $\bar{y}=1.042-0.322 x$ & 0.97 & $24.7^{* *}$ & 0.44 \\
\hline Al Saturation & $\%$ & $\bar{y}=13.21-4.73 x$ & 0.96 & $25.7^{* *}$ & 4.41 \\
\hline Base Saturation & $\%$ & $\hat{y}=17.59+19.9627 x$ & 0.96 & $21.4^{* *}$ & 55.5 \\
\hline Ca Saturation & $\%$ & $\hat{y}=4.0+11.7381 x$ & 0.98 & $51.1^{* *}$ & 27.5 \\
\hline Mg Saturation & $\%$ & $\hat{y}=5.2+7.2030 x$ & 0.88 & $16.6^{* *}$ & 19.6 \\
\hline K Saturation & $\%$ & $\bar{y}=8.0$ & - & $0.2^{\mathrm{ns}}$ & 8.0 \\
\hline \multicolumn{6}{|l|}{ Hylocereus undatus } \\
\hline $\mathrm{pH}_{\text {water }}$ & - & $\hat{y}=5.8+0.3558 x$ & 0.97 & $34.5^{* *}$ & 6.8 \\
\hline $\mathrm{K}$ & $\mathrm{mmol}_{\mathrm{c}} \mathrm{kg}$ & $\hat{y}=3.5+0.4114 x$ & 0.97 & $32.7^{* *}$ & 4.7 \\
\hline $\mathrm{Ca}$ & $\mathrm{mmol}_{\mathrm{c}} \mathrm{kg}$ & $\hat{y}=1.4+6.9137 x$ & 0.99 & $237.4^{* *}$ & 20.8 \\
\hline $\mathrm{Mg}$ & $\mathrm{mmol}_{\mathrm{c}} \mathrm{kg}$ & $\hat{y}=2.1+4.2354 x$ & 0.93 & $23.4 * *$ & 14.0 \\
\hline $\mathrm{Al}$ & $\mathrm{mmol}_{\mathrm{c}} \mathrm{kg}$ & $\bar{y}=1.046-0.309 x$ & 0.94 & $21.6^{*}$ & 0.18 \\
\hline Al Saturation & $\%$ & $\bar{y}=8.942-2.84 x$ & 0.89 & $26.3^{*}$ & 0.99 \\
\hline Base Saturation & $\%$ & $\hat{y}=19.5+18.1763 x$ & 0.95 & $27.7^{* *}$ & 70.4 \\
\hline Ca Saturation & $\%$ & $\hat{y}=4.5+11.7389 x$ & 0.98 & $45.6 * *$ & 34.7 \\
\hline Mg Saturation & $\%$ & $\hat{y}=5.3+7.1264 x$ & 0.88 & $16.5^{* *}$ & 25.3 \\
\hline K Saturation & $\%$ & $\bar{y}=10.4$ & - & $0.6^{\mathrm{ns}}$ & 10.4 \\
\hline
\end{tabular}




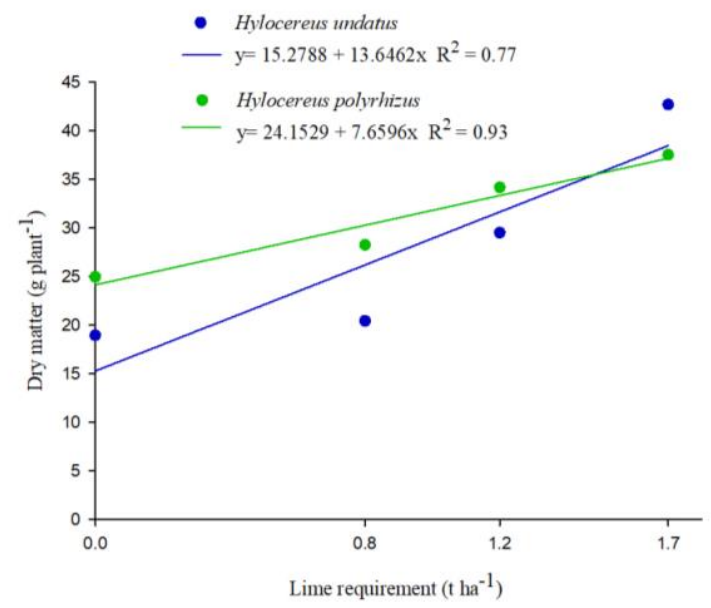

Fig 1. Dry matter production of shoots and roots in the species $H$. undatus and $H$. polyrhizus, according to the lime requirements in Typic Quartzipisamment.

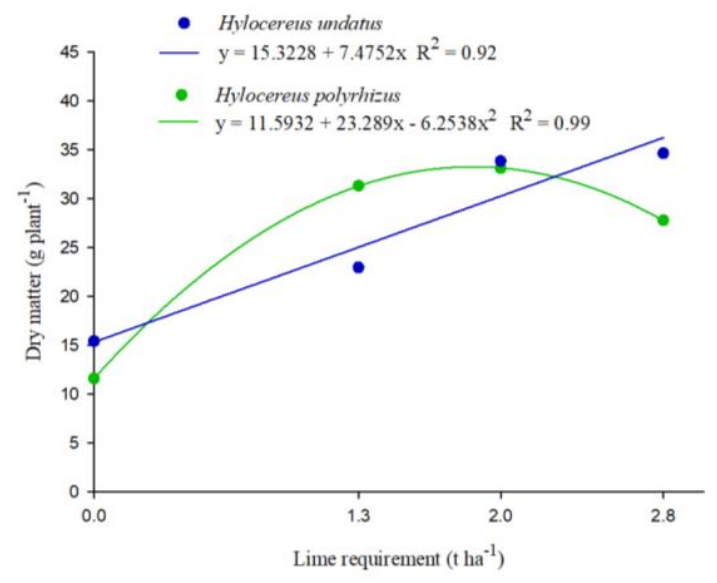

Fig 2. Dry matter production of shoots and roots of the species $H$. undatus and $H$. polyrhizus, according to the lime requirements in Haplorthox.

Table 3. Regression equation and determination of coefficients $\left(R^{2}\right)$ for nutrient concentrations $(\hat{y})$ in cladodes of pitaya species atvarying lime requirements $\left(\mathrm{x}, \mathrm{t} \mathrm{ha}^{-1}\right)$ for Typic Quartzipisamment and Haplorthox, resulting optimal values for nutrient concentration for maximum production of Hylocereus undatus and Hylocereus polyrhizusdry matter.

\begin{tabular}{|c|c|c|c|c|}
\hline Nutrient & Linear regression equation & $\mathrm{R}^{2}$ & F Test & optimal value \\
\hline \multicolumn{5}{|c|}{ Typic Quartzipisamment } \\
\hline \multicolumn{5}{|c|}{ Hylocereus polyrhizus } \\
\hline $\mathrm{N}$ & $\hat{y}=12.5$ & - & $8.1^{\text {ns }}$ & 12.5 \\
\hline$P$ & $\hat{y}=7.9$ & - & $3.4^{\mathrm{ns}}$ & 7.9 \\
\hline K & $\hat{y}=29.3-8.8637 x$ & 0.94 & $24.6 * *$ & 14.2 \\
\hline $\mathrm{Ca}$ & $\hat{y}=52.2+9.8757 x$ & 0.88 & $36.7 * *$ & 69.0 \\
\hline $\mathrm{Mg}$ & $\hat{y}=10.2+0.6605 x$ & 0.96 & $24.8^{* *}$ & 11.3 \\
\hline$S$ & $\hat{y}=0.4$ & - & $6.8^{\mathrm{ns}}$ & 0.4 \\
\hline $\mathrm{Cu}$ & $\hat{y}=1.9$ & - & $2.2^{\mathrm{ns}}$ & 1.9 \\
\hline $\mathrm{Fe}$ & $\hat{y}=106.7-21.0554 x$ & 0.94 & $35.7 * *$ & 70.9 \\
\hline $\mathrm{Mn}$ & $\hat{y}=393.7-141.2460 x$ & 0.99 & $90.1 * *$ & 153.6 \\
\hline $\mathrm{Zn}$ & $\hat{y}=761.4-157.0895 x$ & 0.98 & $40.0^{* *}$ & 494.3 \\
\hline \multicolumn{5}{|c|}{ Hylocereus undatus } \\
\hline $\mathrm{N}$ & $\hat{y}=11.9-1.6032 x$ & 0.98 & $43.8^{* *}$ & 9.2 \\
\hline$P$ & $\hat{y}=7.4$ & - & $2.5^{\mathrm{ns}}$ & 7.4 \\
\hline K & $\hat{y}=23.5-3.6414 x$ & 0.86 & $35.8^{* *}$ & 17.3 \\
\hline $\mathrm{Ca}$ & $\hat{y}=46.8+21.8276 x$ & 0.98 & $49.8^{* *}$ & 83.9 \\
\hline $\mathrm{Mg}$ & $\hat{y}=10.5+0.6583 x$ & 0.99 & $172.8^{* *}$ & 11.6 \\
\hline$S$ & $\hat{y}=0.2+0.1225 x$ & 0.92 & $30.8 * *$ & 0.4 \\
\hline $\mathrm{Cu}$ & $\hat{y}=2.2-0.5281 x$ & 0.92 & $31.2 * *$ & 1.3 \\
\hline
\end{tabular}




\begin{tabular}{|c|c|c|c|c|}
\hline $\mathrm{Fe}$ & $\hat{y}=151.1-40.7152 x$ & 0.93 & $33.4^{* *}$ & 81.9 \\
\hline $\mathrm{Mn}$ & $\hat{y}=256.8-52.6165 x$ & 0.98 & $55.8 * *$ & 167.4 \\
\hline $\mathrm{Zn}$ & $\hat{y}=716.6-107.0012 x$ & 0.96 & $34.5^{* *}$ & 534.8 \\
\hline \multicolumn{5}{|c|}{ Haplorthox } \\
\hline \multicolumn{5}{|c|}{ Hylocereus polyrhizus } \\
\hline $\mathrm{N}$ & $\hat{y}=17.4-1.8602 x$ & 0.98 & $57.2 * *$ & 13.9 \\
\hline$P$ & $\hat{y}=5.9+0.2010 x$ & 0.99 & $119.2^{* *}$ & 6.3 \\
\hline K & $\hat{y}=28.2-3.2995 x$ & 0.90 & $28.5^{* *}$ & 21.6 \\
\hline $\mathrm{Ca}$ & $\hat{y}=59.7+3.8919 x$ & 0.95 & $32.3 * *$ & 67.5 \\
\hline $\mathrm{Mg}$ & $\hat{y}=10.9+0.1993 x$ & 0.97 & $37.8^{* *}$ & 11.3 \\
\hline$S$ & $\hat{y}=0.3$ & - & $5.7^{\mathrm{ns}}$ & 0.3 \\
\hline $\mathrm{Cu}$ & $\hat{y}=3.2-0.6150 x$ & 0.98 & $43.7^{* *}$ & 2.0 \\
\hline $\mathrm{Fe}$ & $\hat{y}=214.5-48.2588 x$ & 0.97 & $34.7^{* *}$ & 118.0 \\
\hline $\mathrm{Mn}$ & $\hat{y}=435.12-107.5128 x$ & 0.98 & $42.9 * *$ & 220.2 \\
\hline $\mathrm{Zn}$ & $\hat{y}=466.8-87.7014 x$ & 0.88 & $27.8^{* *}$ & 291.4 \\
\hline \multicolumn{5}{|c|}{ Hylocereus undatus } \\
\hline $\mathrm{N}$ & $\hat{y}=14.7-1.6309 x$ & 0.99 & $195.4 * *$ & 10.1 \\
\hline$P$ & $\hat{y}=\bar{y}=5.6$ & - & $1.4^{\mathrm{ns}}$ & 5.6 \\
\hline K & $\hat{y}=24.4-3.2174 x$ & 0.91 & $39.8 * *$ & 15.4 \\
\hline $\mathrm{Ca}$ & $\hat{y}=52.9+11.8016 x$ & 0.92 & $41.4^{* *}$ & 85.9 \\
\hline $\mathrm{Mg}$ & $\hat{y}=9.3+1.0448 x$ & 0.98 & $44.3^{* *}$ & 12.2 \\
\hline$S$ & $\hat{y}=0.3+0.1089 x$ & 0.94 & $36.2 * *$ & 0.6 \\
\hline $\mathrm{Cu}$ & $\hat{y}=3.6-1.005 x$ & 0.99 & $101.2^{* *}$ & 0.8 \\
\hline $\mathrm{Fe}$ & $\hat{y}=141.8-16.2886 x$ & 0.96 & $46.1^{* *}$ & 96.2 \\
\hline $\mathrm{Mn}$ & $\hat{y}=256.7-31.8429 x$ & 0.98 & $56.7^{* *}$ & 167.5 \\
\hline $\mathrm{Zn}$ & $\hat{y}=392.5-56.7327 x$ & 0.98 & $46.0 * *$ & 233.6 \\
\hline
\end{tabular}

$\mathrm{N}, \mathrm{P}, \mathrm{K}, \mathrm{Ca}, \mathrm{Mg}$ and $\mathrm{S}\left(\mathrm{g} \mathrm{kg}^{-1}\right) ; \mathrm{Cu}, \mathrm{Fe}, \mathrm{Mn}$ and $\mathrm{Zn}\left(\mathrm{mg} \mathrm{kg}^{-1}\right)$

Table 4. Nutrient concentration in the cladodes of pitaya species, in the second and third year of the pitaya orchard cultivated in Haplorthox with base saturation of $60 \%$.

\begin{tabular}{lccc} 
Nutrient & unit of measurement & $\begin{array}{c}\text { Concentration in the } \\
\text { Second year }\end{array}$ & $\begin{array}{c}\text { Concentration in the } \\
\text { Third year }\end{array}$ \\
\hline $\mathrm{N}$ & $\mathrm{g} \mathrm{kg}^{-1}$ & 11.50 & 18.70 \\
$\mathrm{P}$ & $\mathrm{g} \mathrm{kg}^{-1}$ & 0.93 & 1.20 \\
$\mathrm{~K}$ & $\mathrm{~g} \mathrm{~kg}^{-1}$ & 17.70 & 37.10 \\
$\mathrm{Ca}$ & $\mathrm{g} \mathrm{kg}^{-1}$ & 6.70 & 11.00 \\
$\mathrm{Mg}$ & $\mathrm{g} \mathrm{kg}^{-1}$ & 2.50 & 2.70 \\
$\mathrm{Fe}$ & $\mathrm{mg} \mathrm{kg}^{-1}$ & 29.50 & 68.02 \\
$\mathrm{Mn}$ & $\mathrm{mg} \mathrm{kg}^{-1}$ & 614.40 & 652.00 \\
$\mathrm{Zn}$ & $\mathrm{mg} \mathrm{kg}^{-1}$ & 34.43 & 36.40 \\
\hline
\end{tabular}

work, the concentration observed in plants with the most growth is close to those considered satisfactory in the second and third year at the orchard, with the highest fruit production of $\mathrm{H}$. undatus and $\mathrm{H}$. polyrhizus in Haplorthox soil, saturation at $60 \%$ (table 4 ) (Fernandes et al., 2018).

It is important to note that the work on satisfactory levels of nutrients in pitaya species cultivated in Brazil shows variable results. This is likely related to the soils and orchard management. In a study by Moreira et al. (2012) and Costa et al. (2015) to cultivate $H$. undatus in Haplorthox soil, the fertilization management was carried out using organic sources and the correction was made with a bioclastic granulate. The concentrations considered satisfactory for production varied from $16 \mathrm{~g} \mathrm{~kg}^{-1}$ to $7.6 \mathrm{~g} \mathrm{~kg}^{-1}$ of $\mathrm{N} ; 1.9 \mathrm{~g} \mathrm{~kg}^{-1}$ and $4.1 \mathrm{~g} \mathrm{~kg}^{-1}$ of $\mathrm{P} ; 26 \mathrm{~g} \mathrm{~kg}^{-1}$ and $22.2 \mathrm{~g} \mathrm{~kg}^{-1}$ of $\mathrm{K} ; 19.4$ and $54.3 \mathrm{~g} \mathrm{~kg}^{-1}$ of $\mathrm{Ca}, 5.5 \mathrm{~g} \mathrm{~kg}^{-1}$ and $5.1 \mathrm{~g} \mathrm{~kg}^{-1}$ of $\mathrm{Mg}$.

The greatest differences observed in this work for $\mathrm{Ca}, \mathrm{Mg}$ and $\mathrm{P}$ concentrations are possibly due to the amount of limestone applied in the soil, which provided the best results. This was done to meet the lime requirement of $1.7 \mathrm{t}$ $\mathrm{ha}^{-1}$ in Typic Quartzipisamment soil and $1.9 \mathrm{t} \mathrm{ha}^{-1}$ e $2.8 \mathrm{t} \mathrm{ha}^{-1}$ in Haplorthox soil, which contributed to improving the soil chemical attributes (Table 2). Under these conditions, higher amounts of $\mathrm{CaO}$ and $\mathrm{MgO}$ were added to the soil. In relation to $\mathrm{P}$, liming occurs in the soil $\mathrm{pH}$ by hydroxyl production and this causes the exchangeable $\mathrm{Fe}$ and $\mathrm{Al}$ precipitation, reduces $\mathrm{P}$ precipitation and increases plant availability (Souza et al., 2006).

The results observed in relation to the nutrient concentration demonstrated the importance of liming to cultivate pitaya species since the improvement of soil chemical attributes increases the availability of nutrients that are necessary for plants growth. In this work, the results were noticed in two different soils, illustrating that pitaya species demand high fertility soils and that the correction of the soil acidity must be done in a judicious way to promote the elevation of the $\mathrm{pH}$ between 6.6 to 7.0 and the base saturation around $70 \%$.

\section{Materials and Methods}

\section{Description of treatments and statistical design}

This research was conducted in two experiments; the first was performed in a Typic Quartzipisamment soil and the second experiment in Haplorthox soil. The experiments were conducted in pots inside the greenhouse at the Department of Agronomy of the Federal University of Jequitinhonha and Mucuri Valleys (UFVJM), in Diamantina, MG. Samples of Typic Quartzipisamment soil and Haplorthox soil were taken homogeneously, air-dried and sieved in a $2.0 \mathrm{~mm}$ aperture, 
thus creating a fine soil to be used for chemical analysis and soil texture (Teixeira et al, 2007) (Table 1).

The first experiment was conducted in a $2 \times 4$ factorial scheme with two species of pitaya, Hylocereus undatus $(H$. undatus) and Hylocereus polyrhizus ( $H$. polyrhizus) and four lime requirements $\left(0 ; 0.8 ; 1.2\right.$ and $1.7 \mathrm{t}^{\left.- \text {ha }^{-1}\right)}$ forTypic Quartzipisamment soil, distributed in randomized blocks with five replications. Each plot consisted of five plants of each species. The treatments tested were: T1 (Hylocereus undatus $+0.0 \mathrm{t} \mathrm{ha}^{-1}$ of dolomitic limestone), T2 (Hylocereus undatus $+0.8 \mathrm{t} \mathrm{ha}^{-1}$ of dolomitic limestone), T3 (Hylocereus undatus $+1.2 \mathrm{t} \mathrm{ha}^{-1}$ ofdolomiticlimestone), T4 (Hylocereus undatus $+1.7 \mathrm{t} \mathrm{ha}^{-1}$ of dolomiticlimestone), T5 (Hylocereus polyrhizus $+0.0 \mathrm{t} \mathrm{ha}^{-1}$ of dolomiticlimestone), T6 (Hylocereus polyrhizus $+0.8 \mathrm{t} \mathrm{ha}^{-1}$ of dolomitic limestone), T7 (Hylocereus polyrhizus $+1.2 \mathrm{t} \mathrm{ha}^{-1}$ of dolomiticlimestone) and T8 (Hylocereus polyrhizus $+1.7 \mathrm{t} \mathrm{ha}^{-1}$ of dolomiticlimestone).

The second experiment was also conducted in a $2 \times 4$ factorial scheme, with two species of pitaya, Hylocereus undatus $(H$. undatus) and Hylocereus polyrhizus $(H$. polyrhizus) and four lime requirements $(0 ; 1.3 ; 2.0$ and $2.8 \mathrm{t}$ $\mathrm{ha}^{-1}$ ) for Haplorthox soil, distributed in randomized blocks, with five replications. Each plot consisted of five plants of each species. The treatments tested were: S1 (Hylocereus undatus $+0 \mathrm{t} \mathrm{ha}^{-1}$ of dolomiticlimestone), S2 (Hylocereus undatus $+1.3 \mathrm{t} \mathrm{ha}^{-1}$ of dolomitic limestone), S3 (Hylocereus undatus $+2.0 \mathrm{t} \mathrm{ha}^{-1}$ of dolomitic limestone), S4 (Hylocereus undatus $+2.8 \mathrm{t} \mathrm{ha}^{-1}$ of dolomitic limestone), S5 (Hylocereus polyrhizus $+0.0 \mathrm{t} \mathrm{ha}^{-1}$ of dolomitic limestone), S6 (Hylocereus polyrhizus $+1.3 \mathrm{t} \mathrm{ha}^{-1}$ of dolomitic limestone), S7 (Hylocereus polyrhizus $+2.0 \mathrm{t} \mathrm{ha}^{-1}$ of dolomiticlimestone) and $\mathrm{S} 8$ (Hylocereus polyrhizus $+2.8 \mathrm{t} \mathrm{ha}^{-1}$ of dolomitic limestone).

Lime requirements were established based on increasing the base saturation by 40,60 , and $80 \%$, combined with a control treatment in each soil. Lime requirement (LR) was calculated as LR $\left(\right.$ tha $\left.^{-1}\right)=(\mathrm{V} 2-\mathrm{V} 1) \times$ CEC / 100, where V2 is the established base saturation (40,60 and $80 \%$ ) and $V 1$ is the current base saturation (soil analysis) (Table 1).

\section{Plant material and growth conditions}

The cladodes of the pitaya species used in the two experiments were from the pitaya orchard located at UFVJM, in Diamantina, MG. These cladodes of pitaya were pruned at the apex and standardized at $25 \mathrm{~cm}$. Cladodes underwent a healing period of 15 days to heal the cuts from pruning and were planted in $5.5 \mathrm{~kg}$ of sieved dry soil and placed in pots lined with plastic bags after period of incubation for liming and basal fertilization.

Dolomitic limestone that contained $\left(380 \mathrm{~g} \mathrm{~kg}^{-1}\right.$ of calcium oxide, $125 \mathrm{~g} \mathrm{~kg}^{-1}$ of magnesium oxide, and $90 \%$ total neutralization power) was applied to the soils inside of pots at the rates established in each treatment of both experiments. The soils of both experiments were incubated for a period of 45 days, with humidity of $60 \%$ of field capacity, which was controlled by weighing the soil samples daily. After this period, basal fertilization was accomplished. Basal fertilization to cultivate pitaya species was carried out using the following doses in $\mathrm{mg} \mathrm{kg}^{-1}: 150$ of $\mathrm{N}$; 150 of $\mathrm{K} ; 50 \mathrm{~S}$; 1.0 B; $1.5 \mathrm{Cu}$; 5.0 Fe; 4.0 Mn and 5.0 $\mathrm{Zn}$. The sources of pure reagents used for analysis were: $\mathrm{NH}_{4} \mathrm{NO}_{3} ; \mathrm{KNO}_{3} ;\left(\mathrm{NH}_{4}\right)_{2} \mathrm{SO}_{4}$; $\mathrm{H}_{3} \mathrm{BO}_{3} ; \mathrm{CuCl}_{2} .5 \mathrm{H}_{2} \mathrm{O}$; $\mathrm{FeSO}_{4} .7 \mathrm{H}_{2} \mathrm{O}$-EDTA; $\mathrm{MnCl}_{2} . \mathrm{H}_{2} \mathrm{O}$ and $\mathrm{ZnSO}_{4} \cdot 7 \mathrm{H}_{2} \mathrm{O}$. Phosphate fertilization was carried out using 81 $\mathrm{mg} \mathrm{kg}{ }^{-1}$, based on the results observed by Moreira et al. (2016) in the cultivation of $H$. undatus.
After basal fertilization, the pots containing the soils were incubated for 15 days, maintaining humidity close to field capacity. After this period, the soil volume in each pot was mixed to remove $50 \mathrm{~cm}^{3}$ samples in each pot prior to planting the pitaya cladodes for chemical soil analysis according to Teixeira et al. (2017).

After the cladodes were rooted and the first shoots emerged, nitrogen fertilization was gradually conducted, with three applications of $50 \mathrm{mg} \mathrm{kg}^{-1}$ of $\mathrm{N}$ every 30 days. The pots were irrigated daily with distilled water to maintain soil moisture close to field capacity during the entire experimental period.

At the end of the eight-month period, the plants were segmented, separating shoots, mainly cladodes and roots. All plant parts were washed in running water and dried in the forced circulation oven at $65{ }^{\circ} \mathrm{C}$ to determine the dry matter.

The shoot dry matter samples were used to determine the nutrient concentration in the plants. These samples were ground and submitted to digestion in nitric perchloric acid [nitric acid (65\% v/v) perchloric acid (70\% v/v), Merck-2:1] according to the methodology described by Malavolta et al. (1997).

The soil chemical attributes of calcium, magnesium and potassium saturation were obtained by assessing the relationship between nutrient concentration multiplied by 100 and divided by the soil cation exchange capacity at $\mathrm{pH}$ 7.0 .

\section{Parameters evaluated and statistical analysis}

The data from the shoot and root dry matter, the chemical attributes of the soil, and the shoot nutrient concentration were submitted to analyses of variance. To evaluate the dry matter, the mass of the shoots and roots was recorded, since it was dry matter produced after limestone doses were applied.

The regression equations were adjusted for each variable, according to the lime requirement for each type of soil from the liming dose that provided the highest dry matter yield in the pitaya species. The adjusted regression equations were used to calculate the values of the appropriate chemical attributes in the soils and the concentration of nutrients.

The $\mathrm{Ca}$ and $\mathrm{Mg}$ requirements were calculated from the average of $\mathrm{Ca}$ and $\mathrm{Mg}$ concentrations found for the two pitaya species, adding the $\mathrm{Ca}$ and $\mathrm{Mg}$ concentrations evaluated in each type of soil.

\section{Conclusions}

The soil acidity interferes with the growth of pitaya, which prefers soils with a pH between 6.6 and 7.0. The $H$. undatus and $H$. polyrhizus species cultivated in Haplorthox presented more growth when the saturation of aluminum in the soil was between $1 \%$ and $4 \%$, the base saturation was between $55 \%$ and $70 \%$ and the requirement of calcium and magnesium was $3.0 \mathrm{cmol}_{c} \mathrm{dm}^{-3}$. The pitaya species cultivated inTypic Quartzipisamment presented more growth when the saturation of aluminum in the soil was between $13 \%$ and $16 \%$, the base saturation was $70 \%$ and the requirement of calcium and magnesium was $2.5 \mathrm{cmol}_{\mathrm{c}} \mathrm{dm}^{-3}$. Liming is a practice that must be performed for the cultivation of pitaya species in acidic soils to raise the $\mathrm{pH}$ and 
base saturation, to reduce aluminum saturation, and to adjust the calcium and magnesium requirements.

Liming to meet the nutritional requirements of pitaya species should be performed according to the chemical attributes of each type of soil.

\section{Acknowledgments}

We thank the Coordination for the Improvement of Higher Education Personnel for providing the master's degree scholarship. We express our gratitude to Lindomar Sousa for his technical assistance in the laboratory throughout this research.

\section{References}

Botin AJV, Hernandez PC, Canto AR (2003) Avances en la etiología y manejo de la pudrición blanda de tallos de pitahaya, Hylocereus undatus H.(Cactaceae). Fitosanidad. 7:11-17.

Costa AC, Ramos JD, Silva FOR, Menezes TP, Moreira, RA, Duarte MH (2015) Organic fertilizer and lithothamnium on the cultivation of red pitaia. Semin Cienc Agrar. 36: 77-88.

Farhoodi A, Coventry DR (2008) Field crop responses to lime in the mid-north region of South Australia. Field Crop Res. 108:45-53.

Fernandes DR, Moreira RA, Cruz MCM, Rabelo, JM, Oliveira J (2018) Improvement of production and fruit quality of pitayas with potassium fertilization. Acta Sci Agron. 40:1-9.

Gorski MR, Soares JCW, Krum DN, Brum LN, De Lima TH, Freitas HM, Coimbra VS (2019) Variabilidade espacial da saturação por bases e da saturação por alumínio do solo, numa catena do pampa, cultivada com soja. Braz J Develop. 5: 3660-3667.

Goulding, KWT (2016) Soil acidification and the importance of liming agricultural soils with particular reference to the United Kingdom. Soil Use Manage. 32: 390-399.

Gunasena HPM, Pushpakumara DKNG, Kariyawasam M (2006) Dragon fruit Hylocereus undatus (Haw.) Britton and Rose. In: Gunasena HPM, Pushpakumara DKNG, Kariyawasam $M$ (ed) Dragon fruit Hylocereus undatus (Haw.) Britton and Rose: a fruit for the future, 1st edn. Sri Lanka Council For Agricultural Policy, Sri Lanka. 119.

Huang Y, Huang Y, Chen G, Liu Y, Pan L, Xiong L (2017) Investigation and evaluation of soil nutrients in pitaya orchard in Guangxi. Southwest China J Agric Sci.30:20352040.

Liu DL, Helyar KR, Conyers MK, Fisher R, Poile G J (2004) Response of wheat, triticale and barley to lime application in semi-arid soils. Field Crop Res. 90:287-301.

Malavolta E (2006) Manual de nutrição mineral de plantas, 1st edn. Agronomica Ceres, Piracicaba. 638.

Malavolta E, Vitti GC, Oliveira SA (1997) Avaliação do estado nutricional das plantas: princípios e aplicações, 2nd edn. Potafos, São Paulo. 319.

Manna MC, Swarup A, Wanjari RH, Mishra B, Shahi DK (2007) Long-term fertilization, manure and liming effects on soil organic matter and crop yields. Soil Till Res.94: 397409.
Mijangos I, Albizu I, Epelde L, Amezaga I, Mendarte S, Garbisu C (2010) Effects of liming on soil properties and plant performance of temperate mountainous grasslands. J Environ Manage. 91:2066-2074.

Mizrahi Y, Nerd A (1999) Climbing and columnar cacti: New arid land fruit crops. In: Janick J (ed) Perspectives on new crops and new uses, 1 st edn. ASHS Press, Alexandria. 358366.

Moreira RA, Cruz MCM, Fernandes DR, Oliveira J (2016) Nutrient accumulation at the initial growth of pitaya plants according to phosphorus fertilization. Pesqui Agropecu Trop. 46:230-237.

Moreira RA, Ramos JD, Araujo NA, Marques VB, Melo PC (2012) Productivity and nutrient levels in cladodes of red pitaya using organic fertilizer and calcified seaweed. Rev Bras Cien Agr. 7:714-719.

Moreira RA, Ramos JD, Araújo NA, Marques VB (2011) Production and quality of pitaya fruits with organic fertilization. Rev Bras Frutic. 33:762-766.

Natale W, Rozane DE, Parent LE, Parent SE (2012) Soil acidity and liming in tropical fruit orchards.Rev Bras Frutic. 34:1294-1306.

Natale W, Prado RDM, Rozane DE, Romualdo LM, Souza HAD, Hernandes A (2008) Resposta da caramboleira a calagem. Rev Bras Frutic. 30:1136-1145.

Raij BV (2011) Acidez e calagem. In: Raij, BV (ed) Fertilidade do Solo e Manejo de Nutrientes, 1st edn. IPNI, Piracicaba. 174-175.

Raij BV, Cantarella H, Quaggio JA, Furlani AMC (1997) Correção da acidez do solo. In: Raij BV, Cantarella H, Quaggio JA, Furlani AMC (ed) Recomendações de adubação e calagem para o estado de São Paulo, 2nd edn. IAC, São Paulo. 13-17.

Rothwell SA, Elphinstone ED, Dodd IC (2015) Liming can decrease legume crop yield and leaf gas exchange by enhancing root to shoot ABA signalling. J Exp Bot. 66:23352345.

Sikiric B, Cakmak D, Saljnikov E, Mrvic V, Jakovljevic M, Stajkovic O, Bogdanovic D (2011) Optimization of macroelement contents in raspberry leaves by liming in an extremely acid soil. Span J Agric Res. 9:329-337.

Sousa DMG, Miranda LN, Oliveira SA (2007) Acidez do solo e sua correção. In: Novais RF, Alvarez VH, Barros NF, Fontes RLF, Cantarutti RB, Neves JCL (ed) Fertilidade do solo, 1st edn, SBCS, Viçosa. 206-268.

Souza RF, Faquin V, Rogério P, Torres F, Baliza DP (2006) Calagem e adubação orgânica: influência na adsorção de fósforo em solos. Rev Bras Cienc Solo. 30:975-983.

Valencia Botín AJ, Cruz Hernández P, Rodríguez Canto A (2003) Avances en la etiología y manejo de la pudrición blanda de tallos de pitahaya, Hylocereus undatus H.(Cactaceae). Fitosanidad, 7(2), 11-17.

Vilela L, Soares WV, Sousa DD, Macedo MCM (2004) Calagem e adubação para pastagens na região do cerrado. In: Sousa DMG, Lobato E (ed) Cerrado - correção do solo e adubação, 2nd edn. Embrapa Informação Tecnológica, Brasília. 41.

Vitti GC, Lima E, Cicarone F (2006). In: Fernandes MS, Souza SR, Santos LA (ed) Cálcio, magnésio e enxofre, 1st edn. SBCS, Viçosa. 301.

Teixeira PC, Donagemma GK, Fontana A, Teixeira WG (2017) Manual for methods of soil analysis. 3nd ed, Embrapa. Brasília, Brazil. 